\title{
Oestrogen and progesterone concentrations in peripheral blood in pregnant red foxes (Vulpes vulpes)
}

\author{
M. Bonnin, M. Mondain-Monval* and B. Dutourné $\dagger$ \\ Laboratoire d'Endocrinologie Expérimentale, Domaine de Carreire-Bordeaux Université II, 146, rue \\ Léo Saignat, 33076 Bordeaux Cedex, France
}

\begin{abstract}
Summary. Oestrogen levels were low during most of gestation, but there was a significant increase $(P<0.05)$ in oestradiol concentrations at implantation. Early pregnancy was characterized by high levels of progesterone which decreased significantly $(P<$ 0.001 ) thereafter, but there was no decline in progesterone or rise in oestrogen levels at parturition. There was no difference in the length of progesterone secretion between pregnant and non-pregnant females.
\end{abstract}

\section{Introduction}

In 1935, Rowlands \& Parkes described the reproductive cycle of the red fox (Vulpes vulpes): oestrus occurs only once a year, between the beginning of January and mid-February. Pregnancy lasts for 52 days and ends in March. After whelping, the corpus luteum persists for up to 5 months (Rowlands \& Parkes, 1935; Fairley, 1970; Bonnin-Laffargue \& Canivenc, 1970; Bonnin-Laffargue, Canivenc \& Lajus-Boué, 1972). Mondain-Monval, Dutourné, Bonnin-Laffargue, Canivenc \& Scholler (1977) have studied the changes in ovarian activity of red foxes throughout the year, but their study did not include mated females. The present investigation was therefore undertaken to examine hormone concentrations during pregnancy and pseudopregnancy and thus extend knowledge on this littleknown species.

\section{Materials and Methods}

Blood samples were taken from the radial vein of pregnant female foxes captured at the earth throughout the reproductive season (January-March). These females were autopsied to obtain information regarding the relationship between the fetal development and progesterone concentration. The body cavity of each female was opened and the uterus dissected out. Blastocysts and embryos were collected and the vertex-coccyx length of the embryos was measured. Uteri with obvious uterine swellings and blastocysts implanting were not dissected but fixed in Bouin's fluid for histological observation of implantation. Four 2-year-old females, kept in our laboratory from the moment they were captured at 3 months of age, were bled twice a week during the presumed reproductive season which was from March to May because vixens in captivity have a delayed oestrus of about 2 months compared to wild vixens (see Seton, cited by Rowlands \& Parkes, 1935).

The blood was collected and centrifuged at $3125 \mathrm{~g}$ for $10 \mathrm{~min}$. The plasma was removed and stored at $-25^{\circ} \mathrm{C}$ until assayed.

The progesterone determinations were carried out by radioimmunoassay with an antiserum to progesterone-11 $\alpha$-BSA raised in sheep. The cross-reactivity measured at $50 \%$ displacement was $2.2 \%$ for $17 \alpha$-hydroxyprogesterone, $8 \%$ for deoxycorticosterone, $1.9 \%$ for corticosterone, $1.1 \%$ for $20 \alpha$ and $20 \beta$ hydroxyprogesterone, and $<1 \%$ for testosterone and androstenedione. An aliquot of 0.05 or 0.1 or $0.2 \mathrm{ml}$ plasma was used for each assay; $4000 \mathrm{~d} / \mathrm{min}$ of $\left[1,2,6,7-{ }^{3} \mathrm{H}\right]$ progesterone were added to estimate procedural losses and the mean recovery was $76.47 \pm 0.66 \%$ (s.e.m., $n=150$ ). Progesterone was extracted by 10 volumes of freshly redistilled petroleum ether (b.p. $40-60^{\circ} \mathrm{C}$ ). The aqueous phase was frozen in a mixture of methanol and solid $\mathrm{CO}_{2}$ and the ether-extractable fraction was decanted into another tube and evaporated to dryness under nitrogen at $40^{\circ} \mathrm{C}$. Assay tubes, containing unknown samples or standard in $0.1 \mathrm{ml}$ phosphate buffer $(\mathrm{pH} \mathrm{7}), 0.1 \mathrm{ml}$ antiserum

* Present address: Fondation pour la Recherche en Hormonologie, 67 Boulevard Pasteur, 94260 Fresnes, France.

$\dagger$ Present address: Centre d'Etudes Biologiques des Animaux Sauvages, 79360 Villiers-en-Bois, France. 
(dilution at $1 / 6000)$ and $0 \cdot 1 \mathrm{ml}\left[1,2,6,7-{ }^{3} \mathrm{H}\right]$ progesterone $(20000 \mathrm{~d} / \mathrm{min})$ in phosphate buffer, were estimated in duplicate for samples and in triplicate for standards. The interassay precision was $13.2 \%$. The lower limit of sensitivity of the assay was $0.2 \mathrm{ng} / \mathrm{ml}$.

The oestrone and oestradiol concentrations were determined by the radioimmunoassay described by Mondain-Monval et al. (1977). The antiserum was raised in rabbits against oestrone-17-(Ocarboxymethyl)oxime-BSA and it shows cross-reactions of $66 \%$ with oestradiol- $17 \beta, 11 \%$ with oestradiol $-17 \alpha, 8 \%$ with oestriol and $<0 \cdot 1 \%$ with corticosterone, progesterone, testosterone and $5 \alpha$-dihydrotestosterone. The samples were transferred to Sephadex LH-20 microcolumns to separate the oestrogens. Without correction for losses the overall recovery was $89.3 \pm 4 \%$ for oestrone and $82 \cdot 3 \pm 3 \cdot 2 \%$ for oestradiol. The detection limit was $6 \mathrm{pg} / \mathrm{ml}$ for oestrone and $5 \mathrm{pg} / \mathrm{ml}$ for oestradiol $(17 \alpha$ and $17 \beta)$. The interassay precision was $10.7 \%$ for oestrone and $10.0 \%$ for oestradiol at concentrations below $80 \mathrm{pg} / \mathrm{ml}$.

The results were tested by Mann-Whitney $U$ tests and Student's $t$ tests.

Table 1. Plasma progestrone and oestrogen concentrations in individual red foxes captured at the earth during the breeding season

\begin{tabular}{|c|c|c|c|c|c|}
\hline Fox no. & Reproductive state & & $\begin{array}{l}\text { Prog. conc. } \\
(\mathrm{ng} / \mathrm{ml})\end{array}$ & $\begin{array}{l}\text { Oestrone conc. } \\
\qquad(\mathrm{pg} / \mathrm{ml})\end{array}$ & $\begin{array}{l}\text { Oestradiol conc. } \\
(\mathrm{pg} / \mathrm{ml})\end{array}$ \\
\hline $\begin{array}{l}1 \\
2 \\
3 \\
4 \\
5 \\
6 \\
7\end{array}$ & Blastocysts in utero & $\begin{array}{c}\text { Progestative } \\
\text { phase }\end{array}$ & $\begin{array}{l}15 \cdot 7 \\
12 \cdot 2 \\
16 \cdot 25 \\
34 \cdot 78 \\
29 \cdot 90 \\
20 \cdot 02 \\
23 \cdot 60\end{array}$ & $\begin{array}{l}41 \\
41 \\
49 \cdot 10 \\
24 \cdot 26 \\
28 \cdot 94 \\
45 \cdot 26 \\
114\end{array}$ & $\begin{array}{l}5 \cdot 2 \\
15 \cdot 4 \\
18 \\
10 \cdot 5 \\
25 \cdot 25 \\
53 \\
42 \cdot 35\end{array}$ \\
\hline \multicolumn{3}{|c|}{ Mean \pm s.e.m. } & $21 \cdot 8 \pm 3 \cdot 08^{a}$ & $49 \cdot 08 \pm 11 \cdot 3$ & $24 \cdot 24 \pm 6 \cdot 59^{d}$ \\
\hline $\begin{array}{r}8 \\
9 \\
10 \\
11 \\
12 \\
13\end{array}$ & $\begin{array}{l}\text { Blastocyst implanting } \\
\text { Blastocyst implanting } \\
\text { Embryo, } 2 \mathrm{~mm} \\
\text { Embryo, } 2 \mathrm{~mm} \\
\text { Embryo, } 3 \mathrm{~mm} \\
\text { Embryo, } 8 \mathrm{~mm}\end{array}$ & Implantation & $\begin{array}{l}23 \cdot 6 \\
20 \cdot 26 \\
32 \cdot 65 \\
34 \cdot 68 \\
15 \cdot 54 \\
12 \cdot 65\end{array}$ & $\begin{array}{l}12 \cdot 3 \\
69 \cdot 3 \\
19 \cdot 80 \\
21 \\
67 \\
46\end{array}$ & $\begin{array}{l}328 \\
69 \cdot 3 \\
16 \cdot 07 \\
21 \cdot 1 \\
49 \cdot 4 \\
74 \cdot 1\end{array}$ \\
\hline \multicolumn{3}{|c|}{ Mean \pm s.e.m. } & $23 \cdot 23 \pm 3 \cdot 14^{b}$ & $57.08 \pm 15.62$ & $92.99 \pm 45 \cdot 80^{e}$ \\
\hline $\begin{array}{l}14 \\
15 \\
16 \\
17 \\
18 \\
19 \\
20 \\
21 \\
22 \\
23 \\
24\end{array}$ & $\begin{array}{l}\text { Embryo, } 13 \mathrm{~mm} \\
\text { Embryo, } 14 \mathrm{~mm} \\
\text { Embryo, } 25 \mathrm{~mm} \\
\text { Embryo, } 63 \mathrm{~mm} \\
\text { Embryo, } 68 \mathrm{~mm} \\
\text { Embryo, } 70 \mathrm{~mm} \\
\text { Embryo, } 70 \mathrm{~mm} \\
\text { Embryo, } 78 \mathrm{~mm} \\
\text { Embryo, } 90 \mathrm{~mm} \\
\text { Embryo, } 95 \mathrm{~mm} \\
\text { Embryo, } 120 \mathrm{~mm} \text { (Day 50-52) }\end{array}$ & $\begin{array}{c}\text { Gestative } \\
\text { phase }\end{array}$ & $\begin{array}{c}7 \cdot 62 \\
11 \cdot 36 \\
11 \cdot 62 \\
8 \cdot 45 \\
17 \cdot 40 \\
11 \cdot 3 \\
16 \\
9 \cdot 94 \\
8 \cdot 42 \\
6 \cdot 52 \\
7 \cdot 40\end{array}$ & $\begin{array}{l}38 \cdot 5 \\
70 \cdot 33 \\
42 \\
74 \\
7 \\
43 \cdot 20 \\
44 \cdot 20 \\
25 \cdot 90 \\
32 \cdot 60 \\
57 \cdot 60 \\
16 \cdot 82\end{array}$ & $\begin{array}{l}32 \cdot 5 \\
47 \cdot 5 \\
35 \cdot 1 \\
81 \cdot 7 \\
14 \cdot 75 \\
16 \cdot 5 \\
51 \cdot 3 \\
20 \cdot 73 \\
13 \cdot 9 \\
23 \cdot 2 \\
19 \cdot 64\end{array}$ \\
\hline \multicolumn{3}{|c|}{ Mean \pm s.e.m. } & $9 \cdot 62 \pm 0.94^{\mathrm{c}}$ & $41 \cdot 1 \pm 6 \cdot 32$ & $32.43 \pm 6.25^{f}$ \\
\hline $\begin{array}{l}25 \\
26 \\
27 \\
28\end{array}$ & \multicolumn{2}{|l|}{ A few hours after parturition } & $\begin{array}{l}6 \cdot 46 \\
8 \cdot 26 \\
9 \cdot 66 \\
8.42\end{array}$ & $29 \cdot 6$ & $16 \cdot 2$ \\
\hline & Mean \pm s.e.m. & & $8 \cdot 20 \pm 0.32$ & & \\
\hline
\end{tabular}

Values significantly different at $P<0.001: a$ versus $c, b$ versus $c$ (Mann-Whitney $U$ test) and $a+b$ versus $c$ (Student's $t$ test). Values significantly different at $P<0.05 ; d$ versus $e, e$ versus $f$ (Mann-Whitney $U$ test). 


\section{Results}

The concentrations of oestrogen and progesterone in the peripheral blood of individual foxes during pregnancy are reported in Table 1.

The plasma oestrogen levels were low during most of gestation and, in this study, oestrone concentrations were higher than those of oestradiol except at the time of implantation when there was a significant increase in oestradiol secretion $(P<0.05)$. Early pregnancy is characterized by high levels of progesterone and implantation was associated with the highest mean concentration. After implantation progesterone levels decreased significantly $(P<0.001)$. There was no significant variation in the plasma progesterone level at parturition or even by several hours after whelping. In one female which was bled during the last 16 days of pregnancy (Table 2) the progesterone concentration just before whelping was relatively high and it fluctuated between 4 and $6 \mathrm{ng} / \mathrm{ml}$ during early lactation.

The profiles of progesterone secretion in the peripheral blood of 4 unmated females are shown in Text-fig. 1. Plasma progesterone concentrations reached values as high as $40-60 \mathrm{ng} / \mathrm{ml}$ soon after oestrus, and then fluctuated at lower levels before falling to values af $2-5 \mathrm{ng} / \mathrm{ml}$ which were maintained for several weeks.

Table 2. Plasma progesterone concentrations in a pregnant vixen captured on 1 February 1977 and bled between 1 and 25 March

\begin{tabular}{lcccccccccc}
\hline $\begin{array}{c}\text { Date of bleeding } \\
\text { (March) }\end{array}$ & 1 & 3 & 4 & 7 & 11 & 14 & $16^{*}$ & 18 & 21 & 25 \\
$\begin{array}{c}\text { Prog. conc. } \\
\text { (ng/ml) }\end{array}$ & 22.91 & 17.21 & 17.70 & 15.24 & 14.56 & 14.12 & 8.62 & 5.77 & 6.05 & 2.68 \\
\hline
\end{tabular}

* Sample taken at 17:00 $\mathrm{h}$; whelping occurred that night.

\section{Discussion}

The present results show that in the red fox the concentrations of progesterone are maximal at the time of implantation and then decrease as gestation progresses. This is contrary to events in other species; in some, a constant high level of progesterone is maintained throughout pregnancy, as in cow (Short, 1961; Stabenfeldt, Osburn \& Ewing, 1970) and goat (Thorburn \& Schneider, 1971), while in others, there is a considerable increase in progesterone after implantation, e.g. in the ewe (Bassett, Oxborrow, Smith \& Thorburn, 1969), coypu (Rowlands \& Heap, 1966) and rat (Wiest, 1970).

A similar profile of progesterone secretion during pregnancy is observed in other canids, such as the blue fox (Møller, 1973) and the domestic dog (Parkes, Bell \& Christie, 1972; Smith \& McDonald, 1974; Hadley, 1975; Gräf, 1978). These observations seem to indicate that, in canids, luteotrophic factors originating from the placenta do not influence the corpus luteum function. Smith \& McDonald (1974) suggested that such factors could be present in the bitch but Hadley (1975) denied this possibility. Hadley (1975) also failed to observe the fall in progesterone concentrations after oestrus and subsequent large rise to peak gestational levels 19-24 days after the first day of oestrus which was described by Smith \& McDonald (1974). Gräf (1978) has confirmed the observations of Smith \& McDonald (1974) and suggested an extra-ovarian source of progesterone for the second increase in serum progesterone concentration observed, which coincides with the time of implantation. We have been unable to clarify the question of whether the corpus luteum is the major site of progesterone production in the red fox. The profile of progesterone secretion in individual vixens throughout pregnancy cannot be studied because fertilization occurs in the wild before capture and is therefore inaccurately known. Also, females abort readily in early pregnancy if they are submitted to manipulation and anaesthesia twice a week for the collection of plasma samples. Laparotomy and ovariectomy in early pregnancy cause abortion (unpublished). Despite individual differences, pregnant foxes showed only a non-significant decline in peripheral progesterone before parturition, unlike the blue fox (Møller, 1973) and the bitch (Smith \& McDonald, 1974; Gräf, 1978) in which progesterone 

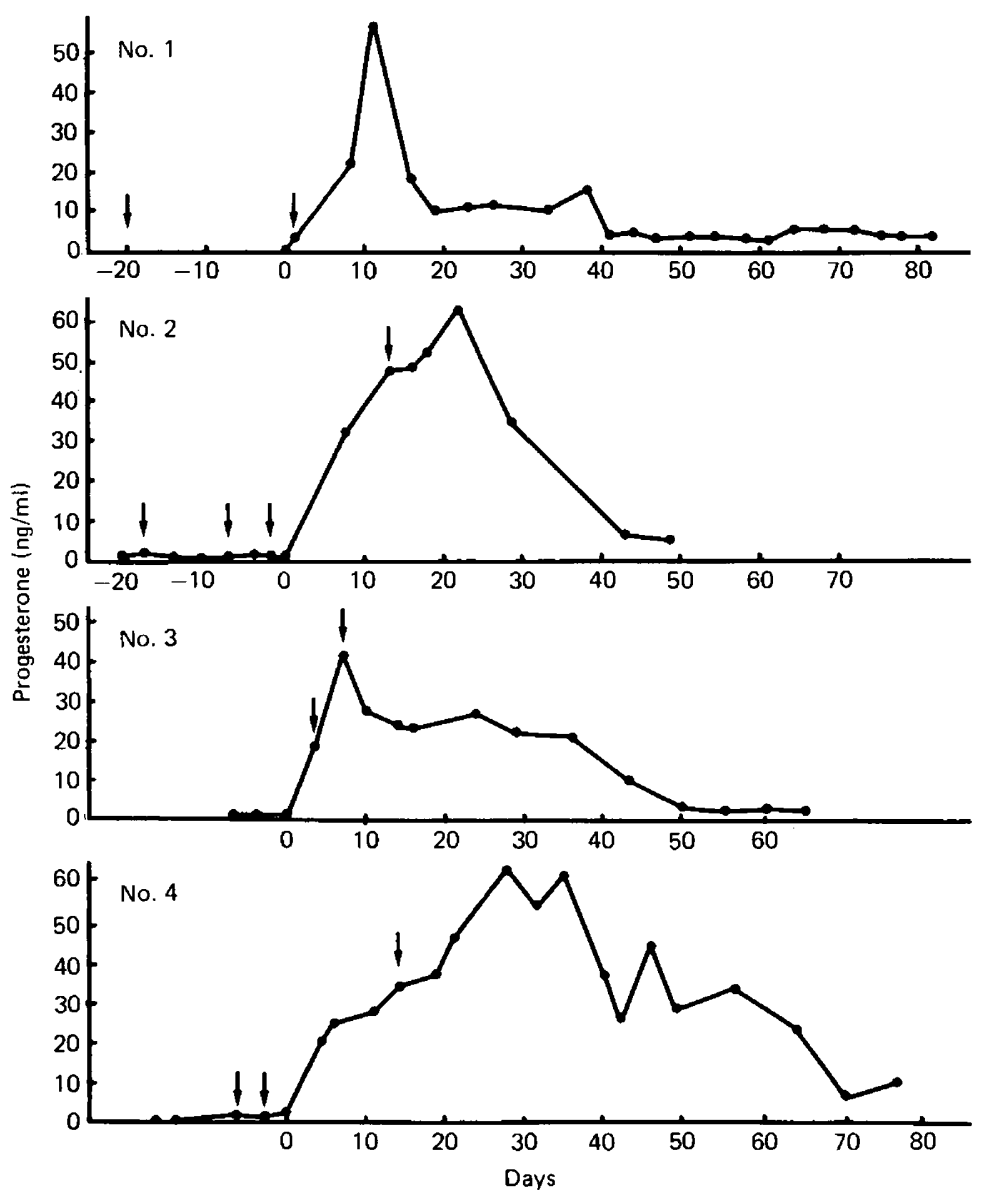

Text-fig. 1. Plasma progesterone concentrations in 4 unmated foxes kept in the laboratory and bled once or twice a week during the reproductive season (in captivity, March-May; see Rowlands \& Parkes, 1935). The arrows indicate the times of the oestradiol peaks indicative of oestrus (see Mondain-Monval et al., 1977). Day 0 is the day before progesterone values increased.

levels fall significantly before whelping. The absence of a decline in peripheral plasma progesterone levels and of a pre-partum rise in oestrogens in the fox raises the question of the mechanism of the initiation of 'parturition. Gräf (1978) has suggested that prolactin is involved in the termination of pregnancy in the bitch and this hormone should, therefore, also be studied in vixens.

In the unmated vixen, despite several phases of oestrogen secretion throughout the year (MondainMonval et al., 1977), spontaneous ovulation occurs only once a year. It has not been possible to determine precisely the lengths of pro-oestrus or oestrus. The period of oestrus can only be indicated by the oestradiol peaks. These peaks are not, however, sufficient to determine the exact time of ovulation because it is known that progesterone can be released before ovulation and before the levels of oestradiol are maximal (blue fox: Møller, 1974; red fox: Mondain-Monval et al., 1977). Pearson \& Enders (1943) have shown histologically that luteinization of the granulosa cells starts in pre-ovulatory follicles in the silver fox. In the present study, this may have occurred in Vixens 2, 3 and 4 (Text-fig. 1) because progesterone secretion increased before the last peak of oestradiol. Despite progesterone concentrations being at much higher levels in unmated pregnant vixens, there does not seem to be any difference between these two categories of females in the length of secretion of progesterone: in unmated females, concentrations are $5 \mathrm{ng} / \mathrm{ml}$ for $50-55$ days after oestrus, a period corresponding to the normal duration of pregnancy. After this time, samples taken regularly from 6 
unmated females for another 150 days contained only low levels of progesterone $(2-6 \mathrm{ng} / \mathrm{ml})$. Corpora lutea have been histologically verified in the ovaries of red foxes 5 months after ovulation, demonstrating their persistence in unmated females. Møller (1973) describes a resemblance between the profiles of progesterone secretion in pseudopregnant and pregnant blue fox females but does not comment on the persistence of corpora lutea in this species. In the bitch also, similar progesterone secretion profiles in pregnancy and pseudopregnancy have been observed by Smith \& McDonald (1974), Hadley (1975) and Gräf (1978). Smith \& McDonald reported progesterone concentrations of about $5 \mathrm{ng} / \mathrm{ml}$ for 90 days in pseudopregnant bitches, but histological observations on the ovaries were not undertaken.

Previous work has demonstrated that pituitary secretions are involved in the persistence of the corpora lutea in the red fox (Bonnin-Laffargue et al., 1972). Since the corpora lutea also persist in unmated females, a biological clock may exist in the maternal hypothalamus which controls the timing of corpus luteum regression.

This work was supported by C.N.R.S. ERA 699. We are indebted to Professor R. V. Short for the gift of progesterone antiserum and to Dr J. Aitken for criticism during preparation of the manuscript.

\section{References}

BassetT, J.M., Oxborrow, T.J., Smith, I.D. \& ThORBURN, G.D. (1969) The concentration of progesterone in the peripheral plasma of the pregnant ewe. J. Endocr. 45, 449-457.

Bonnin-Laffargue, M. \& Canivenc, R. (1970) Biologie lutéale chez le Renard (Vulpes vulpes $L$.). Persistance du corps jaune après la mise bas. C.r. hebd. Séanc. Acad. Sci., Paris D 271, 1402-1405.

Bonnin-Laffargue, M., Canivenc, R. \& Lajus-Boué, M. (1972) Biologie lutéale chez le Renard Vulpes vulpes $L$. L'hypophyse intervient-elle dans la persistance du corps jaune après la mise bas? C.r. hebd. Séanc. Acad. Sci. Paris D 274, 85-88.

FAIRLEY, J.S. (1970) The food, production, form growth and development of the fox Vulpes vulpes $(L)$ in North-East Ireland. Proc. R. Ir. Acad. 69, 103-107.

GRÄF, K.J. (1978) Serum oestrogen, progesterone and prolactin concentrations in cyclic, pregnant and lactating beagle dogs. J. Reprod. Fert. 52, 9-14.

HADLEY, J.C. (1975) Total unconjugated oestrogen and progesterone concentrations in peripheral blood during pregnancy in the dog. $J$. Reprod. Fert. 44, 453-460.

Møller, O.M. (1973) Progesterone concentrations in the peripheral plasma of the blue fox, Alopex lagopus, during pregnancy and the oestrous cycle. J. Endocr. 59, 429-437.

Mondain-Monval, M., Dutourné, B., BonninLaffargue, M., Canivenc, R. \& Scholler, R. (1977) Ovarian activity during the anoestrus and the reproductive season of the red fox (Vulpes vulpes $L$. .). J. Steroid Biochemistry 8, 761-769.

Parkes, M.F., Bell, E.T. \& Christie, D.W. (1972)
Plasma progesterone levels during pregnancy in the beagle bitch. Br. vet. J. 128, 15-16.

Pearson, P.O. \& Enders, R.K. (1943) Ovulation, maturation and fertilization in the fox. Anat. Rec. 85, 69-83.

Rowlands, I.W. \& Heap, R.B. (1966) Histological observations on the ovary and progesterone levels in the coypu (Myocastor coypus). Symp. zool. Soc. Lond. 15, 335-352.

Rowlands, I.W. \& Parkes, A.S. (1935) The reproductive processes of certain mammals. VIII. Reproduction in foxes. (Vulpes spp.). Proc. Zool. Soc. Lond. pp. 823-841.

ShORT, R.V. (1961) Progesterone. In Hormones in Blood) pp. 379-437. Eds G. H. Gray \& A. L. Bacharach. Academic Press, London.

SMith, M.S. \& MCDonald, L.F. (1974) Serum levels of luteinizing hormone and progesterone during the estrous cycle, pseudo-pregnancy and pregnancy in the dog. Endocrinology 94, 405-411.

Stabenfeldt, G.H., Osburn, B.I. \& Ewing, L.L. (1970) Peripheral plasma progesterone levels in the cow during pregnancy and parturition. Am. J. Physiol. 218, 571-575.

Thorburn, G.D. \& SChneider, W. (1971) The progesterone concentration in the plasma of the goat during the oestrous cycle and pregnancy. $J$. Endocr. 50, 307-320.

Wiest, W.G. (1970) Progesterone and 20 $\alpha$-hydroxypregn-4-en-3-one in plasma and uteri during pregnancy in the rat. Endocrinology 87, 43-48.

Received 22 September 1977 